\title{
ISOLASI DAN KARAKTERISASI BAKTERI PENGHASIL SENYAWA ANTIBAKTERI YANG BERASOSIASI DENGAN KARANG BATU DARI PERAIRAN BITUNG DAN SPONS DARI SELAT MAKASSAR
}

\author{
Isolation and Characterization of Bacteria Producing Antibacterial Compound that Associated with Corals and \\ Sponges from Bitung and Selat Makassar
}

\section{FRANSISCA SUNNY, TRI HANDAYANI KURNIATI, \& ARIANI HATMANTI}

Jurusan Biologi FMIPA Universitas Negeri Jakarta (UNJ). Jl. Pemuda No. 10 Rawamangun, Jakarta Timur. 13220. Indonesia.

Email:

Tanggal publikasi online:

\begin{abstract}
Recently the needs of antibacterial compounds is increasing. This is due to the bacterial resistence to common antibacterial compounds. Coral and sponge-associated bacteria are potential producer of antibacterial compounds. This research was aim to obtain coral and sponge-associated bacteria that could produce antibacterial compound. Coral associated-bacteria was isolated from Bitung and was isolated in Marine Agar by pour plate method. The antibacterial compounds were obtained by extraction using ethyl acetate and acetone. The antibacterial assay was performed by agar diffusion method using paper discs and was performed by testing with Staphylococcus aureus, Bacillus subtilis, Vibrio cholerae biotipe El Tor, and Escherichia coli. Total 37 isolate was isolated from corals and 25 isolate from sponge obtained from Selat Makassar. Based on the assay, only bacteria from sponge that showed antibacterial activity. Two sponge-associated bacteria, S.5-8 and S.2-1 NRBC were found to inhibit S. aureus. From those isolates, isolate S.5-8 produced bigger clear zone $(2,6 \mathrm{~mm})$ than S.2-1 NRBC $(1,5 \mathrm{~mm})$. S.5-8 could hydrolize gelatine whereas S.2-1 NRBC showed positive result on oxidase test and was able to fement xilose and arabinose to produce acid.
\end{abstract}

Key words: antibacterial activity, association, characterization, coral, isolation, sponge

\section{PENDAHULUAN}

Saat ini senyawa antibakteri baru sangat dibutuhkan dalam dunia pengobatan. Hal ini diakibatkan beberapa bakteri telah resisten terhadap sedikitnya satu dari senyawa antibakteri yang sudah ada. Sebagai contoh, Klebsiella pneumoniae resisten terhadap antibiotik gentamisin, kloramfenikol, dan tetrasiklin (Sikarwar \& Batra, 2011), sedangkan Serratia marcescens resisten terhadap ceftazidime 
(Yatsuyanagi et al., 2006). Resistensi ini menyebabkan sulitnya penyembuhan beberapa penyakit akibat infeksi bakteri.

Senyawa antibakteri banyak dihasilkan oleh mikroorganisme, terutama bakteri. Bakteri yang mampu menghasilkan senyawa antibakteri antaralain adalah Bacillus cereus dan Pseudoalteromonas phenolica. Bacillus cereus yang diisolasi dari tanah diketahui mampu menghasilkan antibiotik zwittermicin A yang dapat menghambat bakteri Erwinia herbicola (Stabb et al., 1994). Selain itu, menurut Isnansetyo \& Kamei (2003), Pseudoalteromonas phenolica yang diisolasi dari air laut mampu menghambat MRSA (Methicillin-Resistant Staphylococcus aureus).

Bakteri lebih banyak dimanfaatkan dalam industri obat-obatan dibandingkan mikroorganisme lain karena reproduksi bakteri relatif lebih cepat. Selain itu bakteri mudah diperbanyak dalam skala laboratorium sehingga jumlah senyawa antibakteri yang dihasilkan lebih banyak (Abubakar et al., 2011). Bakteri dapat diisolasi dari berbagai habitat, salah satunya adalah laut. Bakteri laut yang berasosiasi dengan invertebrata, termasuk karang batu dan spons, memiliki aktivitas antibakteri yang lebih tinggi dibandingkan bakteri lainnya (Zheng et al., 2005). Dua daerah di Indonesia yang memiliki keanekaragaman karang batu dan spons yang tinggi adalah kota Bitung, di Sulawesi Utara dan Selat Makassar (The Nature Conservancy, 2007 dan Burke et al., 2012). Penelitian ini dilakukan untuk mengisolasi dan mengkarakterisasi bakteri penghasil senyawa antibakteri yang berasosiasi dengan karang batu dari perairan Bitung dan spons dari Selat Makassar. Bakteri ini diharapkan mampu menghambat bakteri patogen, seperti S. aureus, B. subtilis, V. cholerae biotipe El Tor, dan E. coli, sehingga di masa mendatang senyawa antibakteri yang dihasilkan dapat dikembangkan dan dimanfaatkan dalam industri obat-obatan.

\section{METODE PENELITIAN}

\section{Isolasi Bakteri yang Berasosiasi dengan Karang Batu}

Potongan karang batu diinkubasi dalam medium MB 1\% selama 7 hari dalam suhu ruang, kemudian dilakukan proses pengenceran dan isolasi. Isolasi dilakukan dengan metode cawan tuang pada medium MA 1\%. Inkubasi dilakukan 14x24 jam pada suhu ruang. Sementara itu, 25 isolat bakteri yang berasosiasi dengan spons diperoleh dan merupakan hasil koleksi laboratorium mikrobiologi PPO-LIPI (Pusat Penelitian Oseanografi-Lembaga lmu Pengetahuan Indonesia).

\section{Ekstraksi Senyawa Antibakteri}

Sebanyak $5 \mathrm{ml}$ kultur cair bakteri dalam medium MB 100\% yang sudah diinkubasi selama 6 hari, disentrifugasi untuk memisahkan pelet dan supernatannya dengan menggunakan centrifuge berkecepatan $6000 \mathrm{rpm}$ selama 15 menit pada suhu $4{ }^{\circ} \mathrm{C}$.

Ekstraksi senyawa antibakteri dilakukan menurut Murniasih \& Rasyid (2010). Supernatan diekstraksi dengan pemberian etil asetat (1:1), kemudian diinkubasi selama 1 malam (overnight) dalam inkubator orbital. Larutan supernatan lalu dievaporasi sehingga diperoleh endapan. Pelet diekstraksi dengan pemberian aseton (1:1), dengan metode yang sama. Larutan pelet selanjutnya dipisahkan bagian pelet dan supernatannya dengan centrifuge berkecepatan $6000 \mathrm{rpm}$ selama 15 menit pada suhu 4oC. Pelet yang terbentuk kemudian dibuang, sedangkan larutan supernatan 
dievaporasi.

\section{Pengujian Aktivitas Antibakteri}

Ekstrak supernatan dan suspensi pelet masing-masing dilarutkan dengan $90 \mu$ metanol. Sebanyak $15 \mu$ l ekstrak supernatan dan suspensi pelet masing-masing diteteskan pada kertas cakram $6 \mathrm{~mm}$, lalu diuapkan dan diletakkan di atas permukaan medium NA yang sebelumnya sudah digoreskan dengan bakteri uji. Sebagai kontrol positif dan negatif, masing-masing digunakan antibiotik kloramfenikol dan metanol. Inkubasi dilakukan pada suhu 30oC selama 24 jam. Diameter zona hambat yang terbentuk diukur dalam satuan $\mathrm{mm}$. Kemudian, isolat yang memiliki aktivitas antibakteri terbesar selanjutnya dilakukan pengoptimalan terhadap senyawa antibakteri.

Optimalisasi dilakukan melalui 2 cara, yaitu melalui pemekatan ekstrak (penambahan jumlah inokulum bakteri pada kultur cair, penambahan volume kultur cair, dan pengurangan volume metanol) dan penambahan waktu inkubasi kultur cair menjadi 8 hari. Kemudian dilakukan kembali pengujian aktivitas antibakteri dan dilakukan secara triplo.

\section{Karakterisasi Isolat yang Menunjukkan Aktivitas Antibakteri}

Karakterisasi dilakukan melalui pengamatan morfologi koloni dan bentuk sel, pewarnaan Gram, dan pengujian biokimia. Morfologi koloni-koloni yang diamati meliputi warna, bentuk, tepi, elevasi, dan posisi koloni pada medium. Karakterisasi secara biokimia dilakukan dengan kit MicrogenTM dan dilakukan sesuai dengan prosedur yang terdapat pada buku petunjuk kit (Microgen, 2007). Pengujian biokimia meliputi uji oksidase, lisin, ornitin, H2S, glukosa, mannitol, xilosa, ONPG, indole, urease, VP, sitrat, TDA, gelatin, malonat, inositol, sorbitol, rhamnose, sukrosa, laktosa, arabinosa, adonitol, rafinosa, salicin, arginin, dan nitrat.

\section{HASIL DAN PEMBAHASAN}

\section{Isolat Bakteri dari Karang Batu dan Spons}

Isolasi terhadap 12 jenis karang batu menghasilkan 37 isolat bakteri. Hampir semua koloni tumbuh di permukaan medium, sedangkan beberapa koloni tumbuh di dasar medium. Warna koloni terdiri dari coklat, kuning, putih, putih kekuningan, dan putih kebiruan. Koloni isolat paling banyak berbentuk bundar, diikuti dengan bentuk tidak beraturan, konsentris, curled, dan amoeboid. Hampir semua koloni bertepi licin, dan sisanya bertepi berlekuk. Permukaan koloni sebagian besar cembung dan datar, hanya sebagian kecil yang timbul, cekung, dan umboid.

Koloni isolat spons memiliki warna yang beragam, seperti kuning, orange, merah, coklat, putih dan putih kekuningan. Bentuk koloni hampir semua bundar, kecuali 1 isolat yang berbentuk konsentris. Sebagian besar koloni bertepi licin dan hanya sebagian kecil koloni yang bertepi wol, kerang, dan berlekuk. Permukaan koloni sebagian besar timbul dan cembung, hanya sebagian kecil yang permukaannya berbentuk seperti tetesan, dan hanya satu koloni yang permukaannya umboid.

\section{Ekstraksi Senyawa Antibakteri}

Menurut Seidel (2005), senyawa antibakteri yang dihasilkan bakteri, dapat diekskresi oleh 
sel ke medium (ekstraseluler) secara keseluruhan (atau sebagian) dan dapat pula terdapat dalam sel (intraseluler), maka sebelum dilakukan ekstraksi senyawa antibakteri, dilakukan pemisahan sel bakteri dari kultur cair dengan sentrifugasi. Bila senyawa antibakteri diperoleh dari supernatan, maka senyawa tersebut diekskresikan ke lingkungan. Bila senyawa antibakteri diperoleh dari pelet, maka senyawa tersebut terikat pada sel. Karena supernatan merupakan larutan yang bersifat polar, maka pelarut yang digunakan untuk ekstraksi supernatan adalah etil asetat yang bersifat nonpolar. Selain itu, etil asetat dapat bercampur dengan supernatan, bersifat tidak larut dalam air, dan aktivitas senyawa antibakteri yang diekstrak dengan etil asetat lebih tinggi dibandingkan pelarut lainnya (Battu \& Reddy, 2009; Naicker, 2010; dan Jayanth et al., 2002).

Tabel 1. Diameter Zona Hambat pada Kontrol Positif dan Kontrol Negatif

\begin{tabular}{llll}
\hline \multirow{2}{*}{ No } & \multirow{2}{*}{ Bakteri Uji } & Diameter Zona Hambat & \\
\cline { 3 - 4 } & & Kontrol Positif & Kontrol Negatif \\
\hline 1 & B. Subtilis & $26,7 \mathrm{~mm}$ & - \\
2 & S. Aureus & $28,8 \mathrm{~mm}$ & - \\
3 & V. cholerae biotipe El Tor & $28 \mathrm{~mm}$ & - \\
4 & E. Coli & $26 \mathrm{~mm}$ & - \\
\hline
\end{tabular}

Pelarut yang digunakan untuk ekstraksi pelet berbeda dengan ekstraksi supernatan. Hal ini bertujuan untuk memperoleh senyawa antibakteri dengan jenis yang lebih beragam. Pelarut yang digunakan adalah aseton yang bersifat semipolar. Aseton telah terbukti dapat mengekstraksi senyawa antibakteri yang berasal dari pelet kultur cair bakteri (Murniasih \& Rasyid, 2010).

Tabel 4. Hasil pengujian biokimia isolat S.5-8 dan S.2-1 NRBC

\begin{tabular}{|c|c|c|c|c|c|c|c|c|c|c|c|c|c|c|c|c|c|c|c|c|c|c|c|c|c|c|c|c|}
\hline No & Kode & 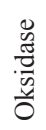 & $\begin{array}{l}\stackrel{\mathscr{I}}{\Xi} \\
\stackrel{\Xi}{\Xi} \\
\Sigma\end{array}$ & $\underset{ت}{ت}$ & $: \stackrel{\Xi}{:}$ & 嘪 & $\tilde{I}$ & 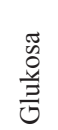 & 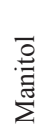 & $\frac{\tilde{D}}{\stackrel{0}{0}}$ & $\begin{array}{l}0 \\
\text { Zे } \\
0\end{array}$ & $\begin{array}{l}\overline{0} \\
\dot{\Xi}\end{array}$ & 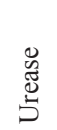 & $\stackrel{s}{s}$ & $\stackrel{\vec{E}}{\vec{E}}$ & 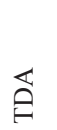 & $\begin{array}{l}\text { 莺 } \\
\frac{0}{0}\end{array}$ & $\begin{array}{l}\frac{\pi}{\tilde{\sigma}} \\
\frac{\bar{\sigma}}{\pi}\end{array}$ & 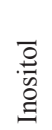 & 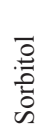 & 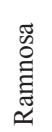 & 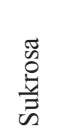 & 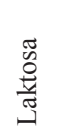 & 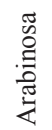 & 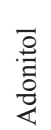 & 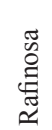 & 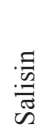 & $\begin{array}{l}\text { 寻 } \\
\text { 娄 }\end{array}$ \\
\hline \multirow{3}{*}{1} & Isolat & & & & & & & & & & & & & & & & & & & & & & & & & & & \\
\hline & S. $5-8$ & - & - & - & - & - & - & - & - & - & - & - & - & - & - & - & + & - & - & - & - & - & - & - & - & - & - & - \\
\hline & S.2-1 & & & & & & & & & & & & & & & & & & & & & & & & & & & \\
\hline 2 & NRBC & + & - & - & - & - & - & - & - & + & - & - & - & - & - & - & - & - & - & - & - & - & - & + & - & - & - & - \\
\hline
\end{tabular}

\section{c. Pengujian Aktivitas Antibakteri}

Berdasarkan hasil dari pengujian aktivitas antibakteri, tidak ditemukan aktivitas antibakteri dari bakteri yang berasosiasi dengan karang batu. Aktivitas antibakteri ditemukan pada 2 isolat bakteri yang berasosiasi dengan spons, yaitu isolat S.5-8 dan S.2-1 NRBC dengan masing-masing diameter zona hambat sebesar 2,6 dan $1,5 \mathrm{~mm}$. Kedua isolat hanya memiliki aktivitas antibakteri terhadap S. aureus. Aktivitas antibakteri kedua isolat tersebut hanya terdapat pada ekstrak supernatan. Hasil pengujian kloramfenikol dan metanol terhadap keempat bakteri uji menunjukkan kloramfenikol memiliki aktivitas antibakteri tertinggi pada S. aureus, yaitu 28,8 mm (Tabel 1), sedangkan pada metanol, tidak terbentuk zona hambat.

Beberapa faktor yang menyebabkan tidak terdapatnya aktivitas antibakteri pada ekstrak 
supernatan dan suspensi pelet bakteri yang berasosiasi dengan karang batu antara lain adanya perubahan sifat isolat karena proses penyimpanan yang lama. Isolat bakteri karang batu yang digunakan dalam pengujian aktivitas antibakteri merupakan isolat yang disimpan dalam jangka waktu kurang lebih 8 bulan dalam medium MA miring. Hasil penelitian Iguchi et al., 2002, menyatakan bahwa bakteri Enterohemorrhagic E. coli O157:H7 yang disimpan selama 25 minggu dalam suhu ruang, mengalami variasi pada pola fragmen PFGE (Pulsed-Field Gel Electrophoresis). Variasi ini terjadi pada minggu ke-5 dan 25. Adanya kemungkinan terjadinya mutasi akibat penyimpanan yang lama dapat menyebabkan hilangnya kemampuan bakteri dalam menghasilkan aktivitas antibakteri.

Penyebab lainnya adalah beberapa bakteri yang berhasil diisolasi tidak dapat memproduksi senyawa-senyawa bioaktif lagi. Kemungkinan bakteri-bakteri tersebut mengharuskan adanya perantara sistem metabolisme dari inangnya (Abubakar, 2009). Selain itu, senyawa antibakteri yang dihasilkan oleh bakteri mungkin saja dihasilkan dalam jumlah sedikit (Seidel, 2005) atau pelarut dan metode ekstraksi yang digunakan tidak sesuai.

Pada bakteri asal spons, senyawa antibakteri ditemukan hanya pada supernatan. Hasil ini selaras dengan yang ditemukan oleh Kanagasabhapathy et al. (2006). Hal ini menunjukkan bahwa senyawa antibakteri diekskresikan seluruhnya ke lingkungan. Di alam, senyawa antibakteri diekskresikan ke lingkungan sebagai upaya untuk berkompetisi dengan bakteri lain, termasuk bakteri patogen pada inang.

Kedua isolat bakteri menunjukkan aktivitas antibakteri terhadap S. aureus yang merupakan bakteri Gram positif, namun tidak terhadap E.coli dan V. cholerae biotipe El Tor yang merupakan bakteri Gram negatif. Adanya aktivitas antibakteri terhadap bakteri Gram positif menunjukkan bahwa bakteri Gram positif lebih rentan terhadap senyawa antibakteri yang dihasilkan oleh bakteri spons. Perbedaan respon terhadap senyawa antibakteri ini disebabkan adanya perbedaan struktur dinding sel kedua bakteri. Bakteri Gram positif tidak memiliki lapisan lipopolisakarida pada dinding selnya, sedangkan pada bakteri Gram negatif, dinding sel dilapisi oleh lapisan lipopolisakarida. Lipopolisakarida merupakan penghalang masuknya senyawa antibakteri. Hal ini menjadikan bakteri Gram negatif lebih tahan terhadap senyawa antibakteri (Paiva et al., 2010 dan Pandey et al., 2004). Diameter zona hambat yang dihasilkan oleh kedua bakteri yang berasosiasi dengan spons (1,5 dan 2,6 mm), lebih kecil dibandingkan diameter kloramfenikol terhadap S. aureus. Hal ini menunjukkan aktivitas senyawa antibakteri yang dihasilkan bakteri lebih rendah dibandingkan kloramfenikol dan spektrumnya sempit karena hanya dapat menghambat bakteri Gram positif dan terbatas pada S aureus saja. Hal yang sama diperoleh Kanagasabhapathy et al. (2006) yang menemukan bahwa bakteri laut memiliki kemampuan yang rendah dalam menghambat bakteri patogen yang bukan merupakan bakteri laut. Kanagasabhapathy et al. (2006) berpendapat hal ini disebabkan karena bakteri laut dan bakteri patogen tidak hidup dalam niche yang sama, sehingga tidak memicu bakteri laut untuk menghasilkan antibakteri untuk melakukan kompetisi. Penyebab lain rendahnya aktivitas senyawa antibakteri mungkin disebabkan karena ekstrak supernatan masih mengandung bahan organik lain sebagai akibat dari metode ekstraksi atau pelarut yang kurang sesuai. 
Hasil positif pada pengujian oksidase terhadap isolat S.2-1 NRBC menunjukkan bahwa bakteri memiliki enzim sitokrom oksidase yang berperan dalam respirasi secara aerob. Pada tahap akhir Setelah dilakukan pengujian, seluruh ekstrak supernatan dan suspensi pelet yang telah dioptimalisasi, tidak menunjukkan adanya zona hambat terhadap seluruh bakteri patogen. Tidak adanya aktivitas antibakteri pada ekstrak supernatan dan suspensi pelet yang dipekatkan dapat disebabkan oleh proses rekultur isolat bakteri yang dilakukan berulang-ulang. Proses rekultur dapat menghasilkan keturunan-keturunan yang memiliki perbedaan genetik dengan sel induknya sehingga bakteri kehilangan kemampuan dalam menghasilkan aktivitas antibakteri. Ini diduga akibat gen yang menyandikan senyawa antibakteri tersebut hilang akibat mutasi atau kehilangan penggerak elemen-elemen genetik yang mensintesis gen-gen tersebut (Abubakar, 2009).

\section{Karakterisasi Bakteri Penghasil Senyawa Antibakteri}

Kedua isolat bakteri merupakan bakteri Gram negatif dan berbentuk basil. Isolat S.5-8 memiliki kemampuan menghidrolisis gelatin. Gelatin merupakan salah satu jenis protein yang harus dipecah terlebih dahulu menjadi molekul lebih kecil (asam amino) sebelum dapat masuk ke dalam sel bakteri dan dimanfaatkan sebagai sumber energi. Hidrolisis gelatin membutuhkan eksoenzim, yaitu gelatinase (Aneja, 2003) yang menghidrolisis gelatin menjadi asam amino (Leboffe \& Pierce, respirasi aerob, terdapat proses fosforilasi oksidatif yang melibatkan rantai transpor elektron. Pada fosforilasi oksidatif, elektron yang berasal dari donor elektron (NADH dan FADH2), akan ditransfer ke akseptor elektron (oksigen) melalui beberapa carrier, sehingga menghasilkan produk akhir berupa air serta menghasilkan sejumlah energi berupa ATP (Prescott et al., 2002). Salah satu molekul pembawa elektron adalah sitokrom c. Enzim sitokrom oksidase akan mengkatalisis oksidasi atau transfer elektron dari sitokrom c ke oksigen, sehingga oksigen akan tereduksi dan menghasilkan air (Michel et al., 1998; Shields \& Cathcart, 2013).

Selain dapat melakukan respirasi aerob, isolat S.2-1 NRBC juga mampu melakukan fermentasi, yaitu fermentasi xilosa dan arabinosa. Fermentasi umumnya dilakukan pada kondisi anaerob (saat tidak ada oksigen). Fermentasi xilosa dan arabinosa menghasilkan produk asam berupa asam laktat dan atau asam asetat (Tanaka et al., 2002). Berdasarkan kemampuan isolat S.2-1 NRBC yang mampu melakukan respirasi aerob dan juga fermentasi, maka dapat disimpulkan bahwa isolat tersebut bersifat anaerob fakultatif.

\section{KESIMPULAN}

Berdasarkan hasil penelitian, diperoleh 2 isolat bakteri yang berasosiasi dengan spons yang memiliki aktivitas antibakteri terhadap S. aureus, yaitu S.5-8 dan S.2-1 NRBC dengan masingmasing diameter zona hambat 1,5 dan 2,6 mm. Isolat S.5-8 memiliki karakteristik biokimia mampu menghidrolisis gelatin, sedangkan isolat S.2-1 NRBC menunjukkan hasil positif pada pengujian oksidase dan mampu memfermentasi xilosa serta arabinosa dengan menghasilkan asam.

\section{DAFTAR PUSTAKA}

Abubakar, H. 2009. Bakteri yang Berasosiasi dengan Spons Jaspis sp. : Analisis Penghasil Senyawa Antimikrob dan Keragaman Genetiknya. Tesis. Institut Pertanian Bogor. Dipublikasikan: 
$62 \mathrm{hlm}$.

Abubakar, H., A.T. Wahyudi, \& M. Yuhana. 2011. Skrining Bakteri yang Berasosiasi dengan Spons Jaspis sp. sebagai Penghasil Senyawa Antimikroba. Ilmu Kelautan. 16 (1): 35-40.

Aneja, K.R. 2003. Experiments in Microbiology, Plant Pathology and Biotechnology Fourth Edition. New Age International, New Delhi: 607 hlm.

Battu, P.R. \& M.S. Reddy. 2009. Isolation of secondary metabolites from Pseudomonas fluorescens and its Characterization. Asian J. Research Chem. 2(1): 26-29.

Burke, L., K. Reytar, M. Spalding, \& A. Perry. 2012. Menengok Kembali Terumbu Karang yang Terancam di Segitiga Terumbu Karang. Terj. dari Reefs at Risk Revisited in the Coral Triangle, oleh Yayasan TERANGI. World Resources Institute, Washington, DC: $90 \mathrm{hlm}$.

dela Cruz T.E.E \& J.M.O. Torres. 2013. Gelatin Hydrolysis Test Protocol: 11 hlm. http://www. microbelibrary.org/library/laboratory-test/3776-gelatin-hydrolysis-test-protocol, $\quad 9$ Februari 2014, pk. 10.07 WIB.

Iguchi, A., R. Osawa, J. Kawano, A. Shimizu, J. Terajima, \& H. Watanabe. 2002. Effects of Repeated Subculturing and Prolonged Storage at Room Temperature of Enterohemorrhagic Escherichia coli O157:H7 on Pulsed-Field Gel Electrophoresis Profiles. J. CLIN. MICROBIOL. 40 (8): 3079-3081.

Isnansetyo, A. \& Y. Kamei. 2003. MC21-A, a Bactericidal Antibiotic Produced by a New Marine Bacterium, Pseudoalteromonas phenolica sp. nov. O-BC30T, against Methicillin-Resistant Staphylococcus aureus. Antimicrobial Agents and Chemotherapy. 47 (2): 480-488.

Jayanh, K., G. Jeyasekaran, \& R. Jeya Shakila. 2001. Isolation of marine bacteria, antagonistic to human pathogens. Indian J. Mar. Sci., 31 (1): 39-44.

Kanagasabhapathy, M., H. Sasaki, S. Haldar, S. Yamasaki, \& S. Nagata. 2006. Antibacterial Activities of Marine Epibiotic Bacteria Isolated from Brown Algae of Japan. Annals of Microbiology. 56 (2): 167-173.

Michel, H., J. Behr, A. Harrenga, \& A. Kannt. 1998. CYTOCHROME C OXIDASE: Structure and Spectroscopy. Annu. Rev. Biophys. Biomol. Struct. 27:329-56.

Microgen. 2007. MicrogenTM GnA+B-ID System. Microgen Bioproducts Ltd, Camberley: 20 hlm.

Murniasih, T. \& A. Rasyid. 2010. Potensi Bakteri yang Berasosiasi dengan Spons Asal Barrang Lompo (Makasar) sebagai Sumber Bahan Antibakteri. Oseanologi dan Limnologi di Indonesia. 36 (3): 281-292.

Naicker, K. 2010. The characterisation of the antimycobacterial activity of a Pseudomonas isolate. Disertasi. University of Witwatersrand. Dipublikasikan: viii $+128 \mathrm{hlm}$.

Paiva, P.M.G., F.S. Gomes, T.H. Napoleão, R.A. Sá, M.T.S. Correia \& L.C.B.B. Coelho. 2010. Antimicrobial activity of secondary metabolites and lectins from plants. Current Research, Technology and Education Topics in Applied Microbiology and Microbial Biotechnology: 396-406. 
Pandey B., Ghimire, P., \& Agrawal, V.P. 2004. Studies on the antibacterial activity of the actinomycetes isolated from the Khumbu Region of Nepal. International Conference and Great Himalayas: Climate, Health, Ecology, Management and Conservation, Kathmandu, January: 12-15.

Prescott, L.M., J. Harley, \& D. Klein. 2002. Microbiology 5th Edition. McGraw-Hill, New York: $1147 \mathrm{hlm}$.

Seidel, V. 2005. Initial and Bulk Extraction. Dalam: Sarker, S.D., Z. Latif, \& A.I. Gray (Eds.). 2005. Natural Products Isolation Second Edition. Humana Press, Totowa, New Jersey: xii $+515 \mathrm{hlm}$.

Shields, P. \& L. Cathcart. 2013. Oxidase Test Protocol: 10 hlm. http://www.microbelibrary.org/ library/laboratory-test/3229-oxidase-test-protocol, 11 Februari 2014, pk. 12:34 WIB.

Sikarwar, A.S \& H.V. Batra. 2011. Challenge to healthcare: Multidrug resistance in Klebsiella pneumoniae. International Conference on Food Engineering and Biotechnology. 9 :130134.

Stabb, E.V., L.M. Jacobson, \& J. Handelsman. 1994. Zwittermicin A- producing strains of Bacillus cereus from diverse soils. Appl. Environ. Microbiol. 60: 4404-4412.

Tanaka, K., A. Komiyama, K. Sonomoto, A. Ishizaki, S. Hall, \& P. Stanbury. 2002. Two different pathways for D-xylose metabolism and the effect of xylose concentration on the yield coefficient of L-lactate in mixed-acid fermentation by the lactic acid bacterium Lactococcus lactis IO-1. Applied Microbiology and Biotechnology. 60: 160-167.

The Nature Conservancy. 2007. Laporan Tahunan 2007. The Nature Consevancy: 47 hlm.

Yatsuyanagi, J., S. Saito, T. Konno, S. Harata, N. Suzuki, J. Kato, \& K. Amano. 2006. Nosocomial Outbreak of Ceftazidime-Resistant Serratia marcescens Strains That Produce a Chromosomal AmpC Variant with N235K Substitution. Jpn. J. Infect. Dis. 59: 153-159.

Zheng, L., X. Han, H. Chen, W. Lin, \& X. Yan. 2005. Marine bacteria associated with marine macroorganisms: the potential antimicrobial resources. Annals of Microbiology. 55: 119124. 